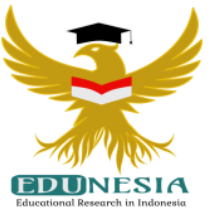

\title{
Peran Ibu Dalam Melatih Pengamalan Beragama Pada Anak Di Lingkungan Keluarga
}

\author{
Muhammad Muslih \\ Pendidikan Agama Islam, Akademi Maritim Cirebon, Indonesia \\ Corresponding Email: muslihmunaya@gmail.com, Phone Number : 0823 xxxx xxxx
}

\author{
Article History: \\ Received: Nov 13, 2020 \\ Revised: Nov 23, 2020 \\ Accepted: Nov 25, 2020 \\ Published: Jan 01, 2021
}

\section{Keywords:}

Family Environment, The

Role of Mother in Practicing

Child Religion.

Kata Kunci:

Lingkungan Keluarga,

Peran Ibu Melatih

Pengamalan Beragama

Anak.

\section{How to cite:}

Muslih, M. (2021). Peran Ibu

Dalam Melatih Pengamalan

Beragama Pada Anak Di

Lingkungan Keluarga. Edunesia:

Jurnal Ilmiah Pendidikan, 2 (1): 162-170.

This is an open access article under the $C C-B Y-N C$-ND license
Abstract: The purpose of this research is to obtain data about knowing the foundations of family education, to explain the economic urgency of education, and to describe the duties of mothers in educating children in the family. This study uses a normative approach, namely library research, then the data is collected and analyzed based on primary data (inventory of books) and those that are related to the discussion techniques of children in the family. The results of this study are that the role of the mother is very influential in practicing the practice in Bergama because the role of the mother is not only a model but also a teacher or educator for her children.This research shows that the family is the first environment that influences one's education, because the institution of the family is a place where humans are first trained to live life. So the family is the first and foremost container for personality development and growth.

Abstrak: Tujuan penelitian adalah untuk memperolah data tentang mengetahui tentang pondasi pendidikan keluarga, menjelaskan tentang urgensi ekonomi bagi pendidikan, dan menjabarkan tentang tugas-tugas ibu dalam mendidik anak dalam keluarga. Penelitian ini menggunakan pendekatan normative, yaitu penelitian Library research(kepustakaan), kemudian data dikumpulkan dan dianalisa berdasarkan data primer (inventaris buku-buku) dan yang ada kaitannya dengan teknik pembahasan anak dalam keluarga.Hasil penelitian ini adalah bahwa peran ibu sangat berpengaruh dalam melatih pengamalan dalam Bergama karena peran ibu bukan hanya sebagai model akan tetapi juga sebagai guru atau pendidik bagi anakanaknya. Penelitian ini adalah bahwa keluarga adalah lingkungan pertama yang mempengaruhi pendidikan seseorang, karena lembaga keluarga merupakan tempat manusia mula-mula digembleng untuk menjalani kehidupan. Maka keluarga merupakan wadah pertama dan utama bagi perkembangan dan pertumbuhan kepribadian. 


\section{A. Pendahuluan}

Seorang Ibu dalam keluarga, tidak dapat diragukan lagi yang dikodratkan untuk hamil, melahirkan, menyusui anakm, maka dalam beberapa tradisi pemberian tanggung jawab atas pendidikan anak dalam keluarga kepada perempuan (ibu). Di era globalisasi perempuan lebih dinamis . tugas pendidik anak dalam keluarga dilakukan secara seimbang antara laki-laki dan perempuan, suami dan istri, antara orang tua dan kerabat lainnya.

Dalam pandangan islam, suami dan istri mempunyai kedudukan yang sama, walaupun keduanya tidak dipandang sebagai sama (oportunitas). Islam tidak pernah menganut deskriminasi yang menguntungkan laki-laki dan merugikan perempuan. Islam juga menggariskan prinsip persamaan antara laki-laki dan perempuan, tetapi tidak berarti keduanya harus sama. Oleh karena adanya perbedaan dan persamaan antara suami dan istri dipahami sebagai pembagian kerja dalam keluarga. (Amina Wadud Muhsin, 2001:195)

Di era globalisasi perempuan lebih dinamis. Tugas pendidik anak dalam keluarga dilakukan secara seimbang antara laki-laki dan perempuan, suami dan istri, antara otang tua dan kerabat lain. Keluarga di era globalisasi mendambakan suasana yang demokratis yaitu adanya kesepakatan emosional dan seksual, hak dan tanggung jawab yang bergantian unsur-unsur yang ada dalam keluarga terintegrasi secara social.

Orang tua merupakan pendidik utama dan pertama bagi anak-anak mereka, karena dari merekalah anak mula-mula menerima pendidikan. Dengan demikian bentuk pertama dari pendidikan terdapat dalam keluarga. Pada umumnya pendidikan dalam rumah tangga itu bukan berpangkal tolak dari kesadaran dan pengertian yang lahir dari pengetahuan mendidik, melainkan karena secara kodrati suasana dan strukturnya memberikan kemungkinan alami membangun situasi pendidikan. Situasi pendidikan itu terwujud berkat adanya pergaulan dan hubungan pengaruh mempengaruhi secara timbal balik antara orang tua dan anak (Darajat. 2012).

Prilaku sosial anak pada awalnya terbentuk melalui hubungan dengan ibu. Ibulah sumber pertama keberhasilan atau kegagalan anak dalam berkomunikasi dengan lingkungan sosial. Apabila dia merasa bahagia dengan ibunya, maka dia mencari lagi kebahagian dengan orang lain sehingga memperbanyak pengalamannya tentang kebahagiaan.

Ibu adalah orang yang sangat penting dalam meletakan fondasi bagi pembentukan karakter anak-anaknya. Ibulah yang meletakan fondasi dasar atas prilaku dan karakter anak. Karena melalui air susunya dia memberikan makanan untuk tubuh, melalui ajarannya, dia memeperkuat jiwanya. Akibatnya anak tersebut mewarisi perilaku, kebiasaan dan karakter lainnya dari ibunya sejak dari bayi dan akan menjumpainya hingga sepanjang hidupnya. Akhirnya kebahagiaan didapatkan darinya.

Di dalam al-Qur'an disebutkan bahwa Allah mewasiatkan setiap manusia agar berbuat baik kepada kedua orang tuanya setelah perintah beribadah dan menghilangkan kemusyrikan kepada Allah dan lebih khusus kepada ibu, karena ia memiliki keutamaan sebagaimana Firman Allah dalam al-Qur'an surat Lukman: 14 yang artinya "Dan Kami perintahkan kepada manusia (berbuat baik) kepada dua orang ibu-bapaknya: ibunya telah mengandungnya dalam keadaan lemah yang bertambah-tambah, dan menyapihnya dalam dua tahun. Bersyukurlah kepada Ku dan kepada dua orang ibu bapakmu, hanya kepadaKulah kembalimu".

State of the art penelitian ini diambil dari beberapa contoh penelitian terdahulu sebagai panduan ataupun contoh untuk penelitian yang dilakukan saat ini. Salah satu jurnal tersebut berjudul "Peran Orang Tua Dalam Penerapan Pendidikan Agama Dan Moral Bagi Anak" Nuraini Staf Pengajar Fakultas Agama Islam Unmuh Ponorogo pada tahun 2013 
yang menjelaskan peran orang tua dalam penerapan pendidikan agama dan moral bagi anak. Pendidikan agama tidak hanya terbatas pada lingkungan sekolah oleh guru saja, tetapi juga oleh siapa saja, kapan saja dan dimana saja. Era globalisasi merupakan era dimana banyak sekali kebudayaan yang masuk ke Indonesia yang sarat dengan krisis moral itu sendiri. Banyak kebudayaan dari Barat (umumnya) yang membawa dampak negatif bagi masyarakat Indonesia baik yang masih anak-anak ataupun sudah dewasa. Keluarga merupakan lapangan pendidikan yang pertama dan pendidiknya adalah kedua orang tua. Orang tua (bapak dan ibu) adalah pendidik kodrati, pendidik bagi anak-anaknya karena secara kodrati ibu dan bapak diberikan anugrah oleh Tuhan berupa naluri orang tua. Dengan naluri ini timbul rasa kasih sayang para orang tua kepada anakanak mereka, hingga secara moral keduanya terbebani rasa tanggung jawab untuk memelihara serta membimbing keturunan mereka. Pendidikan dalam keluarga ini akan membentuk jiwa keagamaan seorang anak. Peneliti meneliti permasalahan ini karena ketertarikan dalam menganalisis peran ibu yang selama ini di lihat sebagai pengasuh di rumah bukan karena di jadikan pengasuh akan tetapi ibu dituntut sebagai seorang pendidik dan model dalam hal kebaikan supaya anak bisa mencontoh apa yang dilakukan oleh orang tua (Ibu), keterbaruan dalam penelitian ini bahwa penelitian ini di kususkan pada lingkungan keluarga karena lingkungan yang bisa mempengaruhi anak itu ada banyak maka dari itu peneliti lebih tertarik melakukan penelitian ini kususnya pada lingkungan keluarga karena peran ibu sangat penting sekali.

\section{B. Metode}

Penelitian ini menggunakan pendekatan normative, yaitu penelitian Library research(kepustakaan), kemudian data dikumpulkan dan dianalisa berdasarkan data primer (inventaris buku-buku) dan yang ada kaitannya dengan teknik pembahasan anak dalam keluarga.

\section{Hasil dan Pembahasan}

Hasil

Urgensi pendidikan keluarga dalam pembentukan pribadi anak memiliki peran yang sangat besar. Dalam konsep pendidikan islam terdapat tiga aspek pembinaan kepribadian anak yang harus diperhatikan yaitu aspek jasmani, rohani, dan akal. kesemuanya harus dikembangkan dengan serasi dan seimbang, sehingga akan membawa anak kepada perkembangan yang baik dan seimbang, sehingga akan membawa anak kepada perkembangan yang baik dan kearah kehidupan yang bahagia didunia dan diakhirat. Disitulah maka akhlak merupakan dasar yang utama dalam pembentukan pribadi anak manusia yang seutuhnya. Pendidikan yang mengarah pada terbentuknya pribadi berakhlak mulia, merupakan hal pertama yang harus dilakukan, sebab akan melandasi kestabilan kepribadian manusia secara keseluruhan.

\section{Pembahasan}

\section{Dasar - dasar Pendidikan dalam Keluarga}

Istilah pendidikan berasal dari bahasa Yunani, Paedagogy, yang mengandung makna seorang anak yang pergi dan pulang sekolah diantar seorang pelayan. Dalam bahasa Romawi, pendidikan diistilahkan dengan educate yang berarti mengeluarkan sesuatu yang berada di dalam. Dalam bahasa Inggris, pendidikan berarti mengeluarkan sesuatu yang 
berada di dalam. Dalam bahasa Inggris, pendidikan diistilahkan to educate yang berarti memperbaiki moral dan melatih intelektual (Suwarno, 2009)

Lembaga pendidikan sebagai salah satu bentuk sistem sosial, senantiasa bersifat terbuka, artinya pendidikan tersebut selalu menerima masukan (input) dari lingkungan, dan memberikan hasil berupa output pada lingkungan juga. Keberhasilan suatu lembaga pendidikan dalam mencapai tujuannya dipengaruhi oleh kondisi dan situasi yang ada disekelilingnya. Oleh karena itu untuk memahami pendidikan secara lebih luas, guru dan pendidik pada umumnya ang berperan sebagai ujung tombak dalam melaksanakan proses pembelaaran, perlu memiliki pemahaman yang jelas tentang konsep lingkungan dan lingkungan pendidikan. Pemahaman yang jelas tentang lingkungan pendidikan tersebut akan mendorong para guru untuk berupaya secara optimal memanfaatkan lingkungan tersebut sehingga memiliki kontribusi yang besar terhadap keberhasilan pendidikan (Sadulloh,2009).

Pendidikan adalah segala usaha orang dewasa dalam pergaulan dengan anak-anak untuk memimpin perkembangan jasmani dan rohaninya kearah kedewasaan (Rasyid, 2007). Menurut Padil \& Suprayitno (2007) Pengertian keluarga adalah a group of two person or more person residing together who are related by blood, marriage, or adoption (sekelompok yang terdiri dari dua orang atau lebih yang mempunyai hubungan darah, pernikahan, atau adopsi).

Dalam pengertian lain, keluarga merupakan sebuah institusi yang terbentuk karena ikatan perkawinan dengan suatu tekad dan cita-cita untuk membentuk keluarga bahagia dan sejahtera lahir batin (Djamarah, 2014).

\section{Komponen Pendidikan Agama Islam Dalam Keluarga.}

Berdasarkan tujuan pendidikan Islam, materi yang disampaikan dalam hal ini berupa:

1. Pendidikan Akidah atau keimanan

Pendidikan keimanan tidak hanya keimanan kepada Allah SWT tetapi meliputi rukun iman yang enam dan hal-hal yang erat hubungannya dengan rukun iman tersebut. Ruang lingkup pengajaran keimanan itu meliputi rukun iman yang enam, yaitu, kepada kitab-kitab suci yang diturunkan kepada Rasul Allah, kepada Malaikat, kepada kitabkitab suci yang diturunkan kepada Rasul Allah, kepada hari kahirat, dan kepada qodho dan qodar. Tentu saja semua hal tersebut, termasuk ruang lingkup pengajaran ini, seperti percaya kepada ghaib yang disebut dalam wahyu, misalnya masalah mati, masalah syetan/iblis dan jin, masalah azab kubur, alam barzah dan sebagainya. (Darajat, 2012).

2. Pendidikan ibadah

Ibadah adalah segala amal perbuatan seseorang hamba sebagai tanda pengabdiannya kepada Allah yang berpedoman kepada Al-Quran serta al-Sunnah dalam meraih keridhoan-Nya menciptakan kita.

3. Pendidikan Akhlak

Pembentukan moral yang tinggi adalah tujuan dari pendidikan Islam. Ulama dan sarjana-sarjana muslim sepenuh perhatian telah berusaha menanamkan akhlak yang mulia, meresapkan fadhila di dalam jiwa para siswa, membiasakan mereka berpegang pada moral yang tinggi dan menghindari hal-hal yang tercela berfikir secara rohani dan insaniah(perikemanusiaan) serta menggunakan waktu buat belajar. Ilmu-ilmu duniawi dan ilmu-ilmu keagamaan, tanpa memandang kepada keuntungan-keuntungan materi. 


\section{Indikasi ekonomi dalam kesinambungan Pendidikan Anak}

Peranan pendidikan dalam perspektif agama, dalam masyarakat membangun amat dibutuhkan oleh pandangan mastarakat dari dimensi ekonomi, pandangan inilah yang akan menentukan peranan pendidikan agama dalam keluarga dalam pandangan agama, pendidikan memegang peranan penting, islam dating untuk mengubah masyarakat menuju kualitas hidup yang lebih baik, seperti dicerminkan dengan tingkat ketaatan yang tinggi kepada Allah SWT (Rahmat, 1992).

Indikasi kurangnya ekonomi dalam keluarga yang kurang harmonis adalah: anak akan rendah diri, kurangnya perhatian dalam pendidikan, emosional dan intelektualnya kurang terkendali, dan kaku dalam pergaulan.

Dalam usaha memaksimalkan pendapatan ekonomi keluarga diperlukan adanya 4 aspek dimensi ekonomi yaitu; 1). Menentukan pencapaian pendidikan secara dini. 2). Menentukan hubungan antara pertumbuhan ekonomi dengan pendidikan, 3). Membekali aspek skill dan kreativitas anak di lingkungan keluarga, 4). Adanya saling keterkaitan antara suami dan istri yang sudah cerai dalam kelangsungan pendidikan pada anak (Langgulung, 1995).

Keluarga adalah umur kecil yang memiliki pimpinan dan anggota, mempunyai pembagian tugas dan kerja, serta hal dan kewajiban lain bagi masing-masing anggotanya, harus mengikuti perubahan social ekonomi yang bersifat koperatif terhadap kebijakan pendidikan anak-anaknya (Shihab, 1992).

\section{Peranan ekonomi Keluarga dalam Pendidikan Agama Anak}

Dalam hal ini dijelaskan oleh Abdullah bahwa "Tampaklah aspek social ekonomi dari khalifah harus demikian dipelihara, pendidikan yang mengingkari dorongan ekonomi keluarga adalah pendidikan yang tidak mempunyai alas an memadai, dorongan akan rasa pentingnya ekonomi bagi peranan agama, yang harus diprioritaskan".

Jika anak dibesarkan dengan celaan, ia belajar memaki. Jika anak dibesarkan dengan ekonomi cukup pendidikannya akan sukses. Jikka anak dibesarkan dengan permusuhan, ia belajar berkelahi. Jika anak dibesarkan dengan cemoohan, ia belajar rendah diri.dan jika anak dibesarkan dengan dukungan keluarga ia belajar mengenai dirinya (Rahmat, 1992).

Muthahari menjelaskan bahwa "oleh karena itu suatu keluarga harus suci. Harus baik sehingga tercipta suatu generasi Islam dan yang dapat merealisaikan norma-norma Islam, menjadi norma-norma teladan yang langsung yang diambil dari rasul maka terjadilah kesehatan mental psikologi anak stabil"

Kebiasaan menduduki kedudukan sangat istimewa dalam kehidupan manusia, ia menghemat banyak sekali kekuatan manusai karena sudah menjadi kebiasaan yang akan membentuk pendidikan jasmani dan kesehatan mental yang harus ada di tengah keluarga.

\section{Ibu Sebagai Pendidik Utama}

Peran dan tanggung jawab orang tua adalah mendidik, mengasuh dan membina setiap pribadi anak. Untuk itu, keberadaan keluarga harus senantiasa memberikan dan mewariskan pengalaman edukatifilahiah yang dialogis dan dinamis, sesuai dengan perkembangan tuntutan zamannya. Kondisi ini sangat baik bagi tumbuhnya kepribadian anak secara optimal (Ahid, 2010). 
Peranan pendidikan yang sepatutnya dipegang oleh keluarga terhadap anggotaanggotanya, secara umum adalah peranan yang paling pokok dibanding dengan peranan lembaga pendidikan (Langgulung, 1995).

Prilaku orang tua akan terpantul pada kelakuan anaknya, apalagi seorang ibu yang secara fitrahnya memiliki sifat lembut, halus dan yang paling dekat dengan anak-anaknya. Oleh karena itu ibu yang bijaksana adalah ibu yang bisa dan pandai mendidik anankanaknya kejalan lebih baik dalam rangka menyiapkan generasi muda yang lebih baik pula.

Pada saat ini pula, anak membutuhkan adanya figur teladan yang tampak di depan matanya. Maka hanya dengan melihat orang tuanya, yang senantiasa mengajarkan shalat lima waktu sehari semalam tanpa sedikit pun mengeluh dan bosan, hal itu akan memberikan pengaruh yang sangat besar dalam diri sang anak. (Zakariya \& Hana, 2011).

Membina ketaatan ibadah pada anak juga mulai dari dalam keluarga dengan membimbing dan mengajarkan atau melatih anak dengan ajran agama seperti syahadat, shalat, berwudhu, doa-doa, bacaan Al-Qur'an. Lafas zikir dan akhlak terpuji, seperti bersyukur ketika mendapatkan anugrah, bersikap jujur, menjalin persaudaraan dengan orang lain, dan menjauhkan diri dari perbuatan yang dilarang Allah (Yusuf,2010).

Sedangkan dalam buku Muhyiddin Abdul Hamid dalam bukunya Kegelisahan Rasulullah Mendengar Tangis Anak yang mengatakan bahwa "perilaku keseharian orang tua yang disaksikan dan dirasakan anak termasuk hal yang memiliki bekas dan pengaruh tersendiri di dalam jiwa dan kepribadian anak. Sehingga dari interaksi sehari-hari antara orang tua dan anak terjadi proses peneladanan (modeling)"(Hamid, 1994).

Mekanisme psikologis kehidupan beragama pada masa kanak-kanak yang sangat menonjol adalah mekanisme imitasi. Seperti perkembangan aspek-aspek psikologis dan kemampuan anak yang lain yang berkembang lewat proses peniruan, pada mulanya anak beragama karena meniru orang tua nya. Dengan demikian jika anak-anak melakukan suatu ibadah (pergi ke masjid, gereja, kuit atau biara) semua itu dilakukan hanya karena meniru orang tuanya saja (Subandi, 2013).

Adapun menurut Suryati Armaiyn dalam bukunya Catatan Hati Sang Bunda yang mengatakan bahwa "seorang ibu, sebagaimana juga ayah, haruslah menjadi teladan bagi anak anaknya. Sebab kedua orang tualah yang paling dekat dengan mereka dibandingkan siapapun. Dan cara atau metode terbaik untuk pendidikan anak di dalam keluarga adalah keteladanan (Suryati, 2011).

\section{Tugas Ibu Dalam Mendidik Anak}

Dalam upaya menghassilkan generasi penerus yang tangguh dan berkualitas, diperlukan adanya usaha yang konsisten dan kontinu dari orang tua di dalam melaksanakan tugas memelihara, mengasuh dan mendidik anak-anak mereka baik lahir maupun batin sampai anak tersebut dewasa dan atau mampu berdiri sendiri, dimana tugas ini merupakan kewajiban orang tua. Begitu pula halnya terhadap pasangan suami istri yang berakhir perceraian, ayah dan ibu tetap berkewajiban untuk memelihara, mengasuh dan mendidik anak-anaknya (Gunawan, 2013).

Dalam rangka pendidikan bahwa kaum ibu memang melebihi kaum pria. Dalam kaitan ini saya berharap agar kepribadian juga memancarkan segi pendidikan bagi keluarga dan lingkungan kita. Keseluruhan penampilan wanita muslimah yang ideal hendaknya berkaitan dengan pendidikan yang ditujukan kepada anak-anak dan juga lingkungan sekitar (Prabuningrat, 1997). 
Secara sederhana peran orang tua dapat dijelaskan sebagai kewajiban orang tua kepada anak. Diantaranya adalah orang tua wajib memenuhi hak-hak (kebutuan) anaknya, seperti hak untuk melatih anak menguasai cara-cara mengurus diri, seperti cara makan, buang air, berbicara, berjalan berdoa, sungguh sungguh membekas dalam diri anak karena berkaitan erat dengan perkembangan dirinya sebagai pribadi. Sikap orang tua sangat memengaruhi perkembangan anak. Sikap menerima atau menolak, sikap kasih sayang atau acuh tak acuh, sikap sabar atau tergesa-gesa, sikap melindungi atau membiarkan secara langsung memengaruhi reaksi emosional anak (Hasbullah, 2011).

Adapun sebagai ibu, jangan sampai anak-anak hidup terlantar karena ibu tidak bisa membina anak-anak dalam masalah ekonomi dengan baik. Untuk itu peran ibu sebagai pembina dengan membina anak hidup mandiri tanpa sering bergantung kepada orang lain, juga anak dibiasakan sejak kecil hidup berkecukupan dengan berhemat dan memanfaatkan sesuatu yang sudah ada tidak berlebih-lebihan (Kauma \& Nipan, 1997).

Ketaatan kepada ajaran agama merupakan kebiasaan yang menjadi milik mereka yang mereka pelajari dan para orang tua maupun guru mereka. Bagi mereka sangat mudah untuk menerima ajaran dari orang dewasa walaupun ajaran itu belum mereka sadari sepenuhnya manfaat ajaran tersebut (Ramayulis, 2011).

Pendidikan sebelum Islam, system pendidikan yang dipakai terhadap anak-anak ialah system keras dan kasar dimana-mana di sekolah terdapat cambuk, dimana-mana terdapat hukuman yang kejam. Akan tetapi para pilosofis Islam kemudian memperingatkan akan bahayanya system ini dalam pendidikan dan mereka telah melarang pengguna cambuk dan hukuman yang kejam dan sebaliknya menyarankan cara-cara yang lunak dan lembut, membenarkan kesalahan-kesalahan anak dengan cara-cara yang halus, lunak, lembut dan kasih sayang, serta menyelidiki pula latar belakang yang menyebabkan kekeliruan-kekeliruan tersebut dan berusaha untuk memahami serta menyatakan kepada anak-anak akibat-akibat kekeliruan tersebut.

Dari penjelasan tersebut nyata bahwa orang tua dalam mendidik anaknya perlu kebijakan. Salah-salah dalam mendidik anak akan berakibat fatal, anak nakal, tidak mengenal syukur kepada Allah dan orang tua yang pada akhirnya menjadi generasi yang tidcak berguna bagi kemajuan bangsa dan Negara.

Wanita sebagai istri dalam keluarga harus mempunyai sikap bijaksana dan penuh perhatian kepada anggota keluarga yang bersangkutan dalam mengelola dan menggunakan harta tersebut.

Djumransjah Dalam bukunya Pendidikan Islam Menggali Tradisi Mengukuhkan Eksistensi mengatakan peran seorang ibu sesuai dengan fungsi dan tanggung jawabnya dalam pendidikan anak adalah: 1 . Sumber dan pemberi kasih sayang 2. Mengasuh dan memelihara 3. Tempat mencurahkan isi hati 4. Mengatur kehidupan dalam rumah tangga 5. Pembimbing hubungan pribadi 6. Pendidik dalam segi-segi emosional. (Djumransjah, 2007).

Ibu sejatinya adalah sebagai teladan anak agar anak-anaknya tumbuh sebagai pribadi yang baik, maka dari itu ibu harus mempunyai prilaku yang baik supaya dapat dicontohkan pada anak-anak

Keluarga adalah unit terkecil yang menjadi pendukung dan pembangkit lahirnya bangsa dan masyarakat. Selama pembangkit itu mampu menyalurkan arus yang kuat lagi sehat, selama itu pula masyarakat bangsa akan menjadi sehat dan kuat. Dalam hal ini keluarga mempunyai andil yang besar bagi berdiri dan dan runtuhnya suatu masyarakat. 
Walaupun harus diakui pula bahwa masyarakat secara keseluruhan dapat mempengaruhi pula keadaan keluarganya.

\section{Kesimpulan}

Keluarga adalah lingkungan pertama yang mempengaruhi pendidikan seseorang, karena lembaga keluarga merupakan tempat manusia mula-mula digembleng untuk mengurangi kehidupan. Maka keluarga merupakan wadah pertama dan utama bagi perkembangan dan pertumbuhan kepribadian anak.

Dalam konsep pendidikan Islam, terdapat tiga aspek pembinaan kepribadian anak yang harus diperhatikan untuk memperoleh perhatian yang serius oleh orang tua dilingkungan keluarga yakni aspek jasmani, yakni aspek rohani, dan aspek akal. Kesemuanya harus dikembangkan dengan serasi dan seimbang, sehingga akan membawa anak kepada perkembangan yang baik dan kearah kehidupan yang bahagia di dunia akherat. Disitulah maka akhlak merupakan fondasi yang utama dalam pembentukan pribadi anak manusia seutuhnya.

\section{Daftar Pustaka}

Ahid, N. (2010). Pendidikan Keluarga dalam Perspektif Islam. Pustaka Pelajar: Jogjakarta.

Darajat, Z. (2012). Ilmu Pendidikan Islam. Bumi Aksara: Jakarta.

Djamarah, S.B. (2014). Pola Asuh Orang Tua dan Komunikasi dalam Keluarga. Rineka Cipta: Jakarta.

Djumransjah. (2007). Pendidikan Islam Menggali Tradisi Mengukuhkan Eksistensi. UIN-Malang

Gunawan, H.M. (2013). Pendidikan Agama Islam dalam Keluarga. Akademia Permata Jakarta

Hamid, M.A. (1994). Kegelisahan Rasulullah Mendengar Tangis Anak. Dahara Pres: Semarang.

Hasbullah. (2011). Dasar-dasar Ilmu Pendidikan. Raja Grafindo Persada: Jakarta.

Kauma, F., \& Nipan. (1997). Membimbing Istri Mendampingi Suami. Mitra Pustaka: Yogyakarta.

Langgulung, H. (1995). Manusia dan Pendidikan. Penerbit M-Husna: Jakarta.

Padil, M., \& Suprayitno, T. (2007). Sosiologi Pendidikan. Sukses Offset: Jogjakarta.

Prabuningrat, R.S. (1997). Sosok Wanita Muslimah. PT. Tiara Wacana Yogya: Jogjakarta.

Rahmat, J. (1992). Islam Aktual. Penerbit: Mizan.

Ramayulis. (2011). Psikologi Agama. Kalam Mulia: Jakarta.

Rasyid, M. (2007). Pendidikan Seks. Syiar Media: Semarang. 
Sadulloh, U. (2009). pedagogika. Upi Press: Bandung.

Shihab, M.Q. (1992). Membumikan Al-Qur'an. Penerbit: Mizan

Subandi, M.A. (2013). Psikologi Agama dan Kesehatan Mental. Pustaka Pelajar: Yogyakarta.

Suryati, A. (2011). Catatan sang Bunda. Al-Mawardi Prima: Jakarta.

Suwarno, W. (2009). Dasar-dasar Ilmu Pendidikan. Ar-Ruzz Media: Jogjakarta.

Yusuf, S. (2010). Psikologi Perkembangan Anak dan Remaja. PT. Remaja Rosdakarya: Bandung. Zakariya, A., \& Hana. (2011). Anakku Rajin Shalat. Perum Gumpang Baru: Solo. 